\title{
The Role of Governor as Vice of Central Government in Regional Regulatory Oversight Regional Tax \& Regional Retribution
}

\section{Muhammad Rois *)}

*) Student of Master of Law, Faculty of Law, Universitas Islam Sultan Agung Semarang, Email: roistoyota@gmail.com

\begin{abstract}
.
This study aims to discuss and analyze the role of the Governor as the Representative of the Central Government in the supervision of Regional Regulations on Regional Taxes and Levies in accordance with Act No. 23 of 2014 concerning Regional Government. The research method uses normative juridical. The results show that the mechanism carried out by the Governor as the Representative of the Central Government is the supervision of Regency Regional Regulations concerning Regional Taxes and Regional Retributions according to Act No. 23 of 2014 which prioritizes the evaluation aspects of the draft District/City Regional Regulations concerning Regional Taxes and Regional Levies before obtaining approval .

Keywords: Governor; Supervision; Regional Taxes; Regional Retribution.
\end{abstract}

\section{Introduction}

Indonesia is a country in Southeast Asia which is traversed by the equator, flanked by two oceans (Indian Ocean and Pacific Ocean) and two continents (Asia continent and Australia continent). Indonesia is also one of the largest archipelagic countries in the world, which consists of large islands and small islands, consisting of various ethnic groups and different cultures from Sabang to Merauke. As an archipelagic country that has ethnic and cultural wealth, since the early days of independence, the Indonesian nation has affirmed that it is a unitary state, this is stated in the constitution, namely Article 1 paragraph (1) of the Constitution of the Republic of Indonesia "The State of Indonesia is a Unitary State, which Republican".

Whereas the concept of the Unitary State refers to the form of a state which only recognizes one sovereignty, namely that of the people. This is stated in Article 1 paragraph (2) of the Constitution of the Republic of Indonesia "Sovereignty rests in the hands of the people and is exercised according to the constitution". That in the concept of a Unitary State, power is in the hands of the state (Central Government), namely the President as the holder. government power ${ }^{1}$ do not recognize the existence of a state within the State, then Article 18 paragraph (2) and paragraph (5) of the 1945 Constitution of the Republic of Indonesia states that the Regional Government has the authority to regulate and administer Government Affairs by itself according to the Principles of Autonomy and Assistance Tasks and is granted autonomy the widest possible.

The formation of regional regulations (Perda) to encourage and optimize regional development can only be realized if the formation of regional regulations is supported by means and methods in accordance with statutory regulations, regional needs and local wisdom in earnest. Regarding legislation or the

\footnotetext{
${ }^{1}$ Republic of Indonesia Constitution of 1945. Article 4 paragraph (1).
} 
manufacture of statutory products, not one country can ignore it, especially Indonesia which claims to be a state based on the law. As a rule of law, the government has the task of carrying out public welfare, where the state or government intervenes in taking care of the people's welfare. This becomes an absolute or inevitable in the welfare state. ${ }^{2}$

Autonomy has another meaning than sovereignty (souvreiniteit), where autonomy is an attribute of the State and not an attribute of parts of the State such as Gemeente, Provincie and so on. ${ }^{3}$ These parts of the State can only have rights that come from the State to be able to stand on their own (zelfstandig) but still cannot be considered independent (onafhankelijk), independent from or equal to the State. Therefore, the performance of supervision always moves dynamically to find the right balance between "the freedom given to the regions through autonomy" and "the limits set by the center in maintaining the integrity and unity of governance within the framework of the Unitary State of the Republic of Indonesia".4

The granting of autonomy to regional governments is followed by the division of government affairs. For this reason, the management of handover must be balanced with supervision. In Act No. 23 of 2014 concerning Regional Government, the implementation of supervision of the implementation of regional taxes and levies is carried out by the Governor, which is clearly emphasized in Article 91 paragraph (1) of Act No. 23 of 2014 "In carrying out guidance and supervision of the administration of Government Affairs which become the authority of the district/city Region and the Assistance Task by the regency/city Region, the President is assisted by the governor as the representative of the Central Government "where one of the powers of the Governor as the Deputy of the Central Government is to evaluate the draft District/City Regional Regulation concerning RPJPD, RPJMD, APBD, amendments APBD, 5 .

Act No. 23 of 2014 concerning Regional Government has also divided the affairs of authority between the Central Government, Provincial Governments and Regency/City Governments. The difference in the mechanism for evaluating regional regulations on regional taxes and levies by the Governor is not without legal consequences, the increase in stages will make the evaluation mechanism longer. Based on the description above, the researcher took the title "The Role of Governor as Vice of Central Government in Regional Regulatory Oversight Regional Tax \& Regional Retribution".

Based on the descriptions above, the problems in this study revolve around the problem of the evaluation mechanism of the draft regional regulation on regional taxes and levies. Thus the problems in this research can be formulated, namely: How is the mechanism for monitoring local regulations regarding regional

\footnotetext{
2 Iwan Sulistiyo and, Widayati. Implementasi Asas Keterbukaan Dalam Proses Pembentukan Peraturan Daerah Dalam Rangka Otonomi Daerah Di Kabupaten Kendal. Jurnal Daulat Hukum Vol. 1. No. 1 March 2018. Jurnal.unissula.ac.id/index.php/RH/article/view/2633/1982.

${ }^{3}$ M Nur Sholikin. dkk. (2011). Laporan Kajian Implementasi Pengawasan Perda Oleh Pemerintah Dan Mahkamah Agung. Pusat Kajian Hukum Dan Kebijakan Indonesia.

${ }^{4}$ Ibid.

${ }^{5}$ Republic of Indonesia. Law of the Republic of Indonesia Number 23 of 2014 concerning Regional Government.
} 
taxes and levies by the Governor as the Representative of the Central Government and How is the Strengthening of the Role of the Governor in the Supervision of Regional Regulations on Regional Taxes and Regional Retributions?

\section{Research methods}

The approach method used in this research is the normative juridical method, which is a research that deductively begins by analyzing the provisions contained in the articles of laws and regulations relating to the subject matter of this research. The approach to the problem used in this research is normative juridical. The normative juridical approach refers to the legal norms contained in statutory regulations and court decisions as well as legal norms that exist in society. ${ }^{6}$ The specification of this research is descriptive analytical, which reveals the laws and regulations relating to legal theories that are the object of research. ${ }^{7}$ Considering that the research method used is normative juridical research method, the type of data that is prioritized is secondary data, then primary data as a support. The data obtained will be presented systematically, then will be analyzed descriptively qualitative normative with descriptive and prescriptive analysis.

\section{Results and Discussion}

\subsection{Mechanism of Supervision of Regional Taxes and Levies by the Governor as the Representative of the Central Government}

In the framework of administering governance, the Unitary State of Indonesia is divided into provincial areas and provincial areas consisting of regencies/municipalities. Each of these regions has the right and obligation to regulate and manage its own government affairs in order to increase the efficiency and effectiveness of government administration and services to the community. ${ }^{8}$

Basically the purpose of supervision is to compare the implementation and plans and instructions that have been made, to determine whether there are difficulties, failures and work efficiency and effectiveness to find solutions when there are difficulties, weaknesses and failures or in other words it is called corrective action. ${ }^{9}$ Supervision can be classified as follows:

- Direct and indirect supervision

Direct supervision is supervision that is carried out personally by the leader or supervisor by observing, researching, examining, self-checking "on the spot" at the work place and receiving reports directly from the executor. Meanwhile, indirect supervision is held by studying reports received from the executor, both oral and written, studying public opinions and without supervision. ${ }^{10}$

\footnotetext{
${ }^{6}$ Zainuddin Ali. Op.Cit. p.105.

7 Ibid.

${ }^{8}$ General explanation of Act No. 28 of 2009 concerning Regional Taxes and Regional Charges.

9 Titik Triwulan T. (2011). Hukum Tata Usaha Negara dan Hukum Acara Peradilan Tata Usaha Negara Indonesia. Jakarta: Prenada Media Group. p. 452- 454.

10 BN. Marbun. ((1993). DPRD Pertumbuhan. Masalah dan Masa Depannya. Jakarta: Erlangga. p.77.
} 


\section{- Preventive and Repressive Monitoring}

Although the principle of supervision is preventive, when it is related to the time of execution of the work, a distinction can be made between Preventive Supervision and Repressive Supervision. Preventive Supervision relating to the ratification of Regional Regulations or Kedecisions of certain regional heads, Meanwhile, Repressive Monitoring can take the form of postponement or cancellation. A Regional Regulation or Decree of a Regional Head that is already in effect and has binding power can be suspended or canceled because it is contrary to public interest or higher-level laws and regulations and this supervision is carried out through a post audit by examining the implementation on the spot, requesting an implementation report and so. ${ }^{11}$

- Internal Control and External Control

Internal Control, is the supervision carried out by the apparatus within the organization itself. Basically, supervision must be carried out by the top leaders themselves. However in practice this is not always possible. Meanwhile, External Control is supervision carried out by officials from outside the organization itself.

The supervisory mechanism for Regency/City Regulations concerning Regional Taxes and Regional Charges according to Act No. 23 of 2014 prioritizes the evaluation aspects of the draft Regional Regulations on Regional Taxes and Regional Levies before being approved so that the supervisory mechanism for Regency Regional Regulations concerning Regional Taxes and Regional Charges is preventive, where the results of the evaluation of draft perda which are in accordance with the higher-level laws and regulations and in the public interest can be accepted and determined, while the results of the evaluation of draft perda which are not in accordance with higher-level statutory regulations and in the public interest can make improvements. In addition, the supervisory mechanism for Regency/City Regulations concerning Regional Taxes and Regional Charges is also repressive in nature.

\subsection{Strengthening the Role of the Governor in Supervision of Regional Regulations concerning Regional Taxes and District/City Charges}

That in the context of strengthening the Governor as Deputy of the Central Government, Government Regulation Number 33 of 2018 concerning the Implementation of the Duties and Authorities of the Governor as the Representative of the Central Government has been issued. In this Government Regulation, it is stated that in carrying out guidance and supervision of the administration of government affairs which fall under the authority of the Regency/City and the assistance task by the Regency/City, the President is assisted by the Governor as the Representative of the Central Government.

The Governor as the Deputy of the Central Government in Government Regulation Number 38 of 2018 concerning the Implementation of the Duties and Authorities of the Governor as the Deputy of the Central Government, is given the

\footnotetext{
${ }^{11}$ Philipus. (1999). Pengantar Hukum Administrasi Indonesia. Yogjakarta: Gadjah Mada University Press. p.118-119.
} 
authority to impose sanctions on the Regent/Mayor regarding the implementation of regional government. The disobedience of the Regent/Mayor in terms of not following up on the evaluation results of the Regency/City Regional Regulations concerning Regional Taxes and Regional Charges can be analogous to the disorderly regents/mayors in administering the wheels of government in the regions, because one of the indicators of orderly implementation of regional government by the Regent/Mayor is obeying legislation. The form of sanctions against the Regent/Mayor is not explicitly stated in Act No. 23 of 2014 concerning Regional Government, Regarding the orderly implementation of regional government, it is only stated that the Governor can impose sanctions on the Regent/Mayor in accordance with the provisions of the laws and regulations, however the Governor as the Deputy of the Central Government can impose sanctions on the Regent/Mayor in the form of, among other things, not giving financial assistance to the Regency/City. This can be used to strengthen the role of the Governor as the Representative of the Central Government in conducting guidance and supervision of the implementation of regional government in the Regency/City.

\section{Closing}

In addition to the evaluation mechanism for the Regency Regulation on Regional Taxes and Regional Retributions, the Governor as the Government's Representative is also authorized to provide a Register Number for the draft Regency/City Regulation concerning Regional Taxes and Regional Retributions before being enacted. It is necessary to strengthen the role of the Governor as the Representative of the Central Government in the supervision of Regency/City Regional Regulations concerning Regional Taxes and Regional Charges through the Not Providing a Register Number of Regency/City Regional Regulations concerning Regional Taxes and Regional Charges if the Regency/City Government does not follow up on the results of the evaluation, Test Material of Regulations Districts/Cities concerning Regional Taxes and Regional Charges in judicial institutions, where the Governor is the Representative of the Central Government as the Petitioner. The Governor as the Central Government Representative in carrying out the supervisory function of Regency/City Regional Regulations concerning Regional Taxes and Regional Retributions, it is hoped that the courage to take action outside the Law (discretion) as long as these actions do not conflict with legal objectives, for example the Governor does not provide a Register Number (Noreg ) to Regency/City regional regulations regarding Regional Taxes and Regional Levies if the Regent/Mayor does not comply with the evaluation results. The governor is expected to be able to impose sanctions on the Regent/Mayor regarding the implementation of regional government in accordance with the provisions in Government Regulation Number 38 of 2018 concerning the Implementation of the Duties and Authorities of the Governor as the Deputy of the Central Government.

\section{References}




\section{Journal:}

[1] Iwan Sulistiyo, Widayati. Implementasi Asas Keterbukaan Dalam Proses Pembentukan Peraturan Daerah Dalam Rangka Otonomi Daerah Di Kabupaten Kendal. Jurnal Daulat Hukum Vol. 1. No. 1 March 2018. Jurnal.unissula.ac.id/index.php/RH/article/view/2633/1982.

\section{Books:}

[1] M Nur Sholikin. dkk. (2011). Laporan Kajian Implementasi Pengawasan Perda Oleh Pemerintah Dan Mahkamah Agung. Pusat Kajian Hukum Dan Kebijakan Indonesia. 2011.

[2] Soeryono Soekanto. (1984). Pengantar Penelitian Hukum. Jakarta: UI Press.

[3] Zainuddin Ali. (2019). Metode Penelitian Hukum. Jakarta: Sinar Grafika.

[4] Irawan Soehartono. (1999). Metode Penelitian Sosial Suatu Tehnik Penelitian Bidang Kesejahteraan Sosial Lainnya. Bandung: Remaja Rosda Karya.

[5] Titik Triwulan T. (2011). Hukum Tata Usaha Negara dan Hukum Acara Peradilan Tata Usaha Negara Indonesia. Jakarta: Prenada Media Group.

[6] BN. Marbun. (1993). DPRD Pertumbuhan, Masalah dan Masa Depannya. Jakarta: Erlangga.

[7] Philipus. (1999). Pengantar Hukum Administrasi Indonesia. Yogjakarta: Gadjah Mada University Press.

\section{Regulations:}

[1] Republic of Indonesia Constitution of 1945. Article 4 paragraph (1),

[2] Law of the Republic of Indonesia Number 23 of 2014 concerning Regional Government

[3] General explanation of Act No. 28 of 2009 concerning Regional Taxes and Regional Charges 